\title{
Genetic relationships among native americans based on $\beta$-globin gene cluster haplotype frequencies
}

\author{
Rita de Cassia Mousinho-Ribeiro ${ }^{1}$, Gabriella Pante-de-Sousa ${ }^{1}$, Eduardo José Melo dos Santos ${ }^{1}$ \\ and João Farias Guerreiro \\ ${ }^{1}$ Universidade Federal do Pará, Centro de Ciências Biológicas, Departamento de Fisiologia, \\ Laboratório de Hematologia, Belém, Pará, Brazil. \\ ${ }^{2}$ Universidade Federal do Pará, Centro de Ciências Biológicas, Departamento de Patologia, \\ Laboratório de Genética Humana e Médica, Belém, Pará, Brazil.
}

\begin{abstract}
The distribution of $\beta$-globin gene haplotypes was studied in 209 Amerindians from eight tribes of the Brazilian Amazon: Asurini from Xingú, Awá-Guajá, Parakanã, Urubú-Kaapór, Zoé, Kayapó (Xikrin from the Bacajá village), Katuena, and Tiriyó. Nine different haplotypes were found, two of which (n. 11 and 13) had not been previously identified in Brazilian indigenous populations. Haplotype $2(+---)$ was the most common in all groups studied, with frequencies varying from $70 \%$ to $100 \%$, followed by haplotype $6(-++-+)$, with frequencies between $7 \%$ and $18 \%$. The frequency distribution of the $\beta$-globin gene haplotypes in the eighteen Brazilian Amerindian populations studied to date is characterized by a reduced number of haplotypes (average of 3.5) and low levels of heterozygosity and intrapopulational differentiation, with a single clearly predominant haplotype in most tribes (haplotype 2). The Parakanã, Urubú-Kaapór, Tiriyó and Xavante tribes constitute exceptions, presenting at least four haplotypes with relatively high frequencies. The closest genetic relationships were observed between the Brazilian and the Colombian Amerindians (Wayuu, Kamsa and Inga), and, to a lesser extent, with the Huichol of Mexico. North-American Amerindians are more differentiated and clearly separated from all other tribes, except the Xavante, from Brazil, and the Mapuche, from Argentina. A restricted pool of ancestral haplotypes may explain the low diversity observed among most present-day Brazilian and Colombian Amerindian groups, while interethnic admixture could be the most important factor to explain the high number of haplotypes and high levels of diversity observed in some South-American and most North-American tribes.
\end{abstract}

Key words: DNA polymorphisms, Brazilian Amerindians, genetic diversity.

Received: November 21, 2002; Accepted: June 24, 2003.

\section{Introduction}

The molecular polymorphism of the $\beta$-globin gene cluster was the first nuclear DNA segment widely studied for the analysis of evolutionary relationships among human populations (Wainscoat et al., 1986). The distribution of haplotypes associated with the $\beta \mathrm{A}$ gene is now known for a large number of populations. The data indicate that Africans are the most divergent group, and that the first split separated an African group from an Eurasian one (Wainscoat et al., 1986; Oehme et al., 1985; Antonarakis et al., 1985; Maggio et al., 1986; Kulozik et al., 1986; Ramsay and Jenkins, 1987; Hundrieser et al., 1988a,b;

Send correspodence to João Farias Guerreiro. Universidade Federal do Pará, Centro de Ciências Biológicas, Departamento de Patologia, Laboratório de Genética Humana e Médica, 66075-900 Belém, Pará, Brazil. E-mail: joaofg@ufpa.br.
Yongvanit et al., 1989; Chen et al., 1990; Long et al., 1990; Trent et al., 1990; Shimizu, 1987; Shimizu et al., 1989; Varawalla et al., 1992; Penaloza et al., 1995; Hewitt et al., 1996; Castro-de-Guerra et al., 1997; Fucharoen et al., 1997; Kaufman et al., 1998; Villalobos-Arámbula et al., 2000). The distribution of $\beta A$ haplotypes in Brazilian Amerindian populations was investigated in ten tribes of the Amazon region by Guerreiro et al. $(1992,1994)$ and Bevilacqua et al. (1995), who obtained similar results. Haplotypes 2 and 6 were the most common, and heterozygosity was reduced, as compared to Europeans and Africans. The results also showed that Brazilian Amerindians are closely related to Asians, Polynesians and Micronesians. However, genetic studies of Brazilian Amerindians based on tandemly repeated minisatellite loci have shown that, although heterozygosity and the mean number of alleles are low, there is a marked heterogeneity 
among populations, with distinct patterns of allele distribution in different tribes. This suggests that the study of a small number of tribes may not adequately sample the whole range of genetic variability in Brazilian Amerindians (Zago et al., 1996). Here, we report on the distribution of the $\beta$-globin gene haplotypes in eight new Amerindian tribes from the Amazon region of Brazil, and compare our results with those reported previously for Native American and other human populations.

\section{Subjects and Methods}

The study was performed on apparently unrelated subjects from eight Amerindian tribes from the Brazilian Amazon region: Asurini of the Xingú ( $\left.3^{\circ} 43^{\prime} \mathrm{S} ; 2^{\circ} 27^{\prime} \mathrm{W}\right)$,

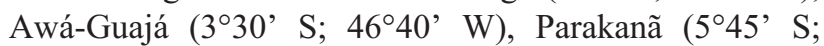
$\left.51^{\circ} 52^{\prime} \mathrm{W}\right)$, Urubú-Kaapór ( $2^{\circ} 48^{\prime} \mathrm{S}$; 46 $\left.{ }^{\circ} 10^{\prime} \mathrm{W}\right)$, Zo’é $\left(0^{\circ} 18^{\prime} \mathrm{N} ; 5^{\circ} 18^{\prime} \mathrm{W}\right)$, Kayapó (Xikrin of Bacajá village;

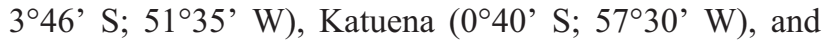
Tiriyó ( $\left.3^{\circ} 30^{\prime} \mathrm{S} ; 53^{\circ} 21^{\prime} \mathrm{W}\right)$.

Blood samples were collected using the anticoagulant EDTA, and genomic DNA was isolated from whole blood by phenol-chloroform extraction and ethanol precipitation (Old and Higgs, 1983). $\beta$-globin gene haplotypes were identified by analyzing the following polymorphic restriction sites: 1. HincII 5'; 2. HindIII G; 3. HindII A; 4.
HincII- $\beta$; 5 . HincII-3' $\beta$. Typing was done by PCR amplification, followed by restriction digestion and agarose gel electrophoresis, according to Guerreiro et al. (1992) for site HincII 5', and to Sutton et al. (1989) for the remaining sites. Haplotype identification was made using the likelihood method described by Excoffier and Slatkin (1995). Haplotype diversity, the gene differentiation coefficient (Nei, 1973, 1978; Livshits and Nei, 1990), and genetic distances (DA distance, as described by Nei et al., 1983) between Brazilian Amerindians and other populations were estimated using the DISPAN program (Ota, 1993). A neighbor-joining tree (Saitou and Nei, 1987) was obtained from DA genetic distances using the same program. Comparisons of the haplotype distribution in different populations were made with Pearson's Chi-square statistic using the Biosys-1 program (Swofford and Selander, 1981).

\section{Results}

Nine different haplotypes were found, two of which (n. 11 and 13) had not been previously identified in Brazilian indigenous populations (Table 1). The number of identified haplotypes per tribe ranged from one in the Awá-Guajá to eight in the Urubú-Kaapór. Haplotype 2 (+ - - -) was the most common in all groups studied, with frequencies varying from $70 \%$ to $100 \%$, followed by haplo-

Table 1 - $\beta$-globin gene haplotypes in Brazilian Amerindians and other native Americans.

\begin{tabular}{|c|c|c|c|c|c|c|c|c|c|c|c|c|c|c|c|c|}
\hline \multirow{2}{*}{$\begin{array}{l}\text { Populations } \\
\text { (number of chromosomes) }\end{array}$} & \multicolumn{16}{|c|}{ Haplotypes } \\
\hline & $\left(\begin{array}{l}1 \\
(-)\end{array}\right.$ & $(+2$ & $\begin{array}{c}3 \\
(-+)\end{array}$ & $\begin{array}{c}4 \\
(-+-+)\end{array}$ & $\begin{array}{c}5 \\
(-+-++)\end{array}$ & $\begin{array}{c}6 \\
(-++-+)\end{array}$ & $\begin{array}{c}7 \\
(-++-)\end{array}$ & $\begin{array}{c}9 \\
(-++++)\end{array}$ & $\begin{array}{c}10 \\
(++-++)\end{array}$ & $\begin{array}{c}11 \\
(-++)\end{array}$ & $\begin{array}{c}12 \\
(++-)\end{array}$ & $\begin{array}{c}13 \\
(+-+)\end{array}$ & $\begin{array}{c}15 \\
(+++-+)\end{array}$ & $\begin{array}{c}16 \\
(-+-)\end{array}$ & $\begin{array}{c}17^{*} \\
(-+-)\end{array}$ & $\begin{array}{c}18^{* *} \\
(+-+-)\end{array}$ \\
\hline Carrier-Sekani, Canada $^{1}(50)$ & & 60.0 & & & 18.0 & 12.0 & & & 6.0 & & & 4.0 & & & & \\
\hline Mvskoke, $\mathrm{USA}^{1}(70)$ & & 45.8 & & & 5.7 & 30.0 & 1.4 & 1.4 & 7.1 & & 1.4 & 1.4 & 3.0 & 1.4 & 1.4 & \\
\hline Huichol, Mexico $^{2}$ (97) & & 79.2 & & 1.0 & 2.2 & & & & 1.0 & & & & 9.1 & 1.0 & & 2.0 \\
\hline Yanomámi, Brazil $^{3}$ (34) & 2.9 & 91.2 & & & & 5.9 & & & & & & & & & & \\
\hline Wayampí, Brazil ${ }^{4}(30)$ & & 86.7 & & & 3.3 & 6.7 & 3.3 & & & & & & & & & \\
\hline Wayana-Apalaí, Brazil ${ }^{4}$ (34) & & 82.4 & & & & 14.7 & & 2.9 & & & & & & & & \\
\hline Wai-Wai, Brazil ${ }^{5}(56)$ & & 87.5 & & & & 12.5 & & & & & & & & & & \\
\hline Katuena, Brazil $^{6}(56)$ & & 92.8 & & & 3.6 & 3.6 & & & & & & & & & & \\
\hline Arára, $\operatorname{Brazil}^{4}(30)$ & & 83.4 & & 3.3 & & 10.0 & & 3.3 & & & & & & & & \\
\hline Gavião, Brazil ${ }^{5}$ (58) & 1.7 & 87.9 & 1.7 & & & 3.4 & 5.2 & & & & & & & & & \\
\hline Zoró, $\operatorname{Brazil}^{5}(60)$ & & 93.3 & & & & 6.7 & & & & & & & & & & \\
\hline Suruí, Brazil ${ }^{5}(44)$ & & 81.8 & & & 4.5 & 11.4 & & & & 2.3 & & & & & & \\
\hline Xavante, Brazil $^{5}(60)$ & & 60.0 & & & 15.0 & 18.3 & 5.0 & & & & & & & 1.7 & & \\
\hline Asurini, Brazil ${ }^{6}(14)$ & & 78,6 & & & 7.1 & 7.1 & 7.1 & & & & & & & & & \\
\hline Awá-Guajá, Brazil ${ }^{6}(86)$ & & 100.0 & & & & & & & & & & & & & & \\
\hline Parakanã, Brazil ${ }^{6}(28)$ & & 78.6 & & 7.1 & & 10.7 & 3.6 & & & & & & & & & \\
\hline Urubú-Kaapór, Brazil ${ }^{6}$ (94) & 4.2 & 70.3 & & 1.1 & 5.3 & 11.7 & & 4.2 & & 2.1 & & 1.1 & & & & \\
\hline Zo'é, Brazil ${ }^{6}$ (50) & & 78.0 & & & 6.0 & 16.0 & & & & & & & & & & \\
\hline Kayapó (Xikrin), Brazil ${ }^{6}$ (40) & & 87.5 & & 2.5 & & 10.0 & & & & & & & & & & \\
\hline 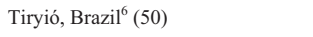 & & 68.0 & & & 4.0 & 18.0 & & 10.0 & & & & & & & & \\
\hline Wayuu, Colombia ${ }^{7}$ (164) & & 94.0 & & 1.2 & 1.2 & 1.2 & & & 1.2 & & & 1.2 & & & & \\
\hline Kamsa, Colombia $^{7}(122)$ & & 87.0 & 1.6 & & & 3.3 & & & & 1.6 & 1.6 & 3.3 & & & & 1.6 \\
\hline Inga, Colombia $^{7}(28)$ & & 93.0 & & & & & & & & & & 7.0 & & & & \\
\hline Mapuche, $\operatorname{Argentina}^{8}(86)$ & 5.8 & 57.0 & 2.3 & 2.3 & 3.5 & 26.7 & 1.2 & & & & & & 1.2 & & & \\
\hline
\end{tabular}

Haplotype numbering according to Long et al. (1990); ${ }^{1}$ Mattevi et al. (2000); ${ }^{2}$ Villalobos-Arámbula et al. 2000; ${ }^{3}$ Guerreiro et al. (1992); ${ }^{4}$ Guerreiro et al . (1994); ${ }^{5}$ Bevilacqua et al. (1995); ${ }^{6}$ present study; ${ }^{7}$ Shimizu et al. (2000); ${ }^{8}$ Kaufman et al. (1998); *haplotype first described in Melanesians by Hill et al. (1988); ** haplotype first described in Japanese by Shimizu et al. (1992). 
type $6(-++-+)$, with frequencies between $7 \%$ and $18 \%$. This haplotype was absent only from the Awá-Guajá sample, in which the frequency of haplotype 2 was $100 \%$. Haplotype $5(-+-++)$ was identified in five of the eight tribes, with frequencies between $3.6 \%$ and $7 \%$, while haplotype $4\left(-+-\right.$ - $\left.^{+}\right)$was observed in three tribes, with frequencies varying from $1 \%$ to $7 \%$. The remaining haplotypes were identified in only one or two tribes, although with polymorphic frequencies in some cases.

The haplotype distribution among the tribes showed statistically significant differences $\left(\chi^{2}=114.607\right.$; D.F. $=56$; $\mathrm{p}<0.001)$. However, these differences were primarily due to the inclusion of the Awá-Guajá, Urubú-Kaapór and Tiriyó, which presented clear differences with regard to the other tribes. When these three populations were excluded, the haplotype distribution was more homogeneous $\left(\chi^{2}=25.032\right.$; D.F. $\left.=16 ; \mathrm{p}=0.069\right)$.

\section{Discussion}

The most common $\beta$-globin gene haplotypes found in Brazilian Amerindians (haplotypes 2, 6, and 5) are considered to be first-order haplotypes in the phylogenetic scheme proposed by Chen et al. (1990) and Long et al. (1990). These haplotypes were probably brought to America by the first settlers of the continent, given that they are also common in Asia, the probable place of origin of the first migrants, and in the islands of the South Pacific, from where additional immigrants may have come (Salzano and Callegari-Jacques, 1988; Nei and Roychoudhury, 1993; Ward et al., 1991; Horai et al., 1993; Neves et al., 1998). According to this scheme, haplotypes 2, 5, and 6 would have originated directly from the ancestral type, possibly haplotype 1 (Chen et al., 1990 and Long et al., 1990) or haplotype 3 (Vincek et al., 1994), or from another firstorder haplotype (1 or 4). First-order haplotypes are separated by at least two mutation or gene conversion events (Long et al., 1990), making it unlikely that they arose in na- tive Americans from other first-order haplotypes, which are virtually absent in these populations. Second-order haplotypes $(7,9,11$, and 13), derived by recombination from first-order haplotypes, were also found in Brazilian natives at frequencies varying from $1.4 \%$ to 10.0 . As they are rare or absent in Asians, they probably appeared during the colonization of the American continent. Three other first-order haplotypes $(3,4$, and 16) were also found at low frequencies in Brazilian Amerindians. The presence of haplotype 3 can be attributed to admixture with people of African ancestry, since this haplotype is very common in Africans, but rare or absent in all other populations. The presence of the other first-order haplotypes (4 and 16) may also be due to admixture with non-Amerindians, although, as they are also found in Asian and Oceanic populations, they may have been present in the ancestral population.

The distribution of $\beta$-globin haplotypes in native Americans is shown in Table 1. To date, eleven different haplotypes have been identified in Brazilian tribes, although most of them have a reduced number of haplotypes (average of 3.5, minimum of 1 , and maximum of 8 ). The highest value was observed in the Urubú-Kaapór, a tribe with significant levels of admixture with non-Amerindians. The haplotype distribution among tribes is generally homogeneous, haplotype 2 accounting for more than $78 \%$ of haplotypes. Haplotype 6 accounts for the majority of the remainder, followed by haplotype 5 , also found in most of the eighteen tribes studied. Awá-Guajá, Parakanã, UrubúKaapór, Tiriyó and Xavante are the exceptions. Haplotype 2 is fixed in the former tribe, while the others present alternative haplotypes with relatively high frequencies.

Genetic variability measured by haplotype diversity and the coefficient of gene differentiation in native American and other ethnic groups is shown in Table 2. Total diversity $(\mathrm{Ht})$ and intrapopulational variation $(\mathrm{Hs})$ observed in Brazilian Amerindians are similar to those estimated for Asians, corroborating the results of Guerreiro et al. (1994) and Mattevi et al. (2000), but they are higher than those es-

Table 2 - $\beta$-globin gene haplotype diversity in American natives and other human populations.

\begin{tabular}{|c|c|c|c|c|c|c|c|}
\hline Population & $\begin{array}{c}\text { N. of } \\
\text { subpopulations }\end{array}$ & $\mathrm{Ht}$ & $\mathrm{Hs}$ & Dst & Dm & Gst & Gst' \\
\hline Africans & 6 & 0.710 & 0.650 & 0.060 & 0.072 & 0.085 & 0.100 \\
\hline Europeans & 5 & 0.820 & 0.590 & 0.030 & 0.038 & 0.280 & 0.060 \\
\hline Asians & 8 & 0.330 & 0.310 & 0.020 & 0.023 & 0.061 & 0.069 \\
\hline North-Americans & 2 & 0.656 & 0.639 & 0.018 & 0.036 & 0.026 & 0.053 \\
\hline South-Americans & 22 & 0.306 & 0.286 & 0.019 & 0.020 & 0.065 & 0.065 \\
\hline Colombian Amerindians & 3 & 0.164 & 0.162 & 0.002 & 0.003 & 0.012 & 0.018 \\
\hline Brazilian Amerindians & 18 & 0.305 & 0.290 & 0.015 & 0.016 & 0.049 & 0.052 \\
\hline Brazilian Amerindians ${ }^{1}$ & 15 & 0.252 & 0.244 & 0.008 & 0.009 & 0.032 & 0.034 \\
\hline
\end{tabular}

Ht, average heterozygosity for the entire population; Hs, average heterozygosity within populations; Dst, interpopulational genetic variation; Dm, average minimum genetic distance among subpopulations; Gst, coefficient of gene differentiation; Gst', coefficient of gene differentiation, considering the number of populations examined. 
timated for Colombian Amerindians and, as expected, lower than those of North-American natives, Africans and Europeans. The interpopulational diversity (Dst) of Brazilian Amerindians is also higher than that observed in Colombian Amerindians, but a little lower than estimated for native North-Americans and Asians. Some of the Brazilian tribes, such as the Urubú-Kaapór and Tiriyó, and probably the Xavante, present evidence of interethnic admixture and exhibit high levels of heterozygosity, which may account for at least part of these differences. However, CallegariJacques and Salzano (1999) estimated interethnic admixture in the Xavante as being only about $2 \%$. Anyway, when these tribes are excluded from diversity analyses, interpopulational diversity in Brazilian Amerindians is reduced to $0.8 \%$, a value lower than those observed in other populations, except for Colombian Amerindians.

The genetic distances (DA) between Brazilian Amerindians and other American natives based on haplotype frequencies are shown in Table 3, and their relationship pattern is presented as a dendrogram (Figure 1). As a rule, the genetic distances between Brazilian Amerindians are low, except for the Urubú-Kaapór and Tiriyó, and the genetic affinities among tribes show no clear linguistic or geographic pattern. At a continental level, the lowest values of genetic distances from Brazilian Amerindians were observed in Colombian Amerindians (Wayuu, Kamsa and Inga) and Huichol (Mexico), who cluster in the upper part of the dendrogram (Figure 1). Mvskoke, Carrier-Sekani and Mapuche are the more differentiated groups, and form a separate cluster.

In summary, the results obtained through analysis of the $\beta$-globin haplotype in a relatively large number of Brazilian Amerindian populations agree with those of the first studies, indicating a homogeneous distribution of haplo-

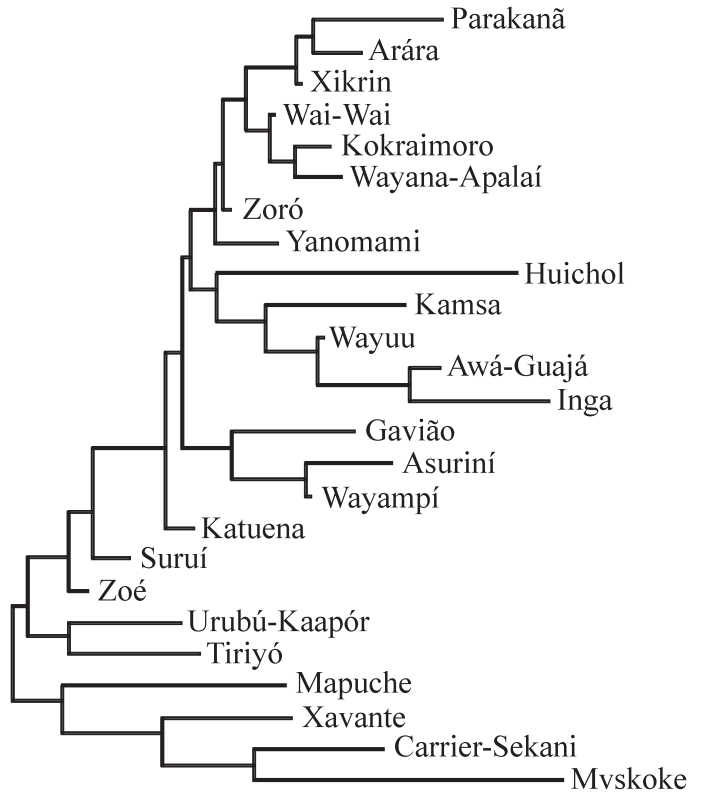

Figure 1 - Dendrogram constructed by the neighbor-joining method, showing the relationships between Amerindian tribes based on $\beta$-globin gene cluster haplotype frequencies.

types in most tribes, characterized by a reduced number of haplotypes, and low levels of heterozygosity and differentiation. Haplotype 2 accounts for more than $78 \%$ of the total, the rest being mainly accounted for by haplotypes 5 and 6 . The Parakanã, Urubú-Kaapór, Tiriyó and Xavante constitute exceptions by presenting at least one other haplotype with a relatively high frequency. The pattern of genetic affinities among Brazilian Amerindians indicates that most groups are closely related to each other, and to Colombian Amerindians, whereas North-American Amerindians are

Table 3 - Heterozygosity (x100) and genetic distances (DA) between Amerindian tribes based on $\beta$-globin haplotypes (X 10,000).

\begin{tabular}{|c|c|c|c|c|c|c|c|c|c|c|c|c|c|c|c|c|c|c|c|c|c|c|c|c|c|}
\hline & Yan & Asu & Awa & Gav & Pak & Sui & Uru & Wpi & Zoe & Zor & Kok & Xav & Xik & Ara & Kat & Tir & Wai & Wap & Map & Wyu & Ksa & Iga & Car & Mvk & Huc \\
\hline Yan & $\underline{16.6}$ & & & & & & & & & & & & & & & & & & & & & & & & \\
\hline Asu & 886 & $\underline{38.0}$ & & & & & & & & & & & & & & & & & & & & & & & \\
\hline Awa & 450 & 1134 & $\underline{0.0}$ & & & & & & & & & & & & & & & & & & & & & & \\
\hline Gav & 377 & 589 & 625 & 22.4 & & & & & & & & & & & & & & & & & & & & & \\
\hline Pak & 739 & 763 & 1134 & 652 & 37.1 & & & & & & & & & & & & & & & & & & & & \\
\hline Sui & 543 & 517 & 956 & 898 & $\overline{877}$ & $\underline{31.8}$ & & & & & & & & & & & & & & & & & & & \\
\hline Uru & 813 & 1042 & 1615 & 1241 & 1168 & 554 & 48.7 & & & & & & & & & & & & & & & & & & \\
\hline Wpi & 479 & 087 & 689 & 379 & 554 & 319 & 889 & $\underline{24.5}$ & & & & & & & & & & & & & & & & & \\
\hline Zoe & 594 & 452 & 1168 & 982 & 862 & 142 & 663 & $\overline{296}$ & $\underline{36.6}$ & & & & & & & & & & & & & & & & \\
\hline Zor & 147 & 747 & 341 & 467 & 590 & 390 & 1016 & 336 & $\overline{434}$ & $\underline{12.6}$ & & & & & & & & & & & & & & & \\
\hline Kok & 385 & 889 & 1084 & 806 & 614 & 407 & 975 & 526 & 314 & $\frac{1216}{216}$ & 32.9 & & & & & & & & & & & & & & \\
\hline Xav & 1564 & 365 & 2254 & 1439 & 1309 & 728 & 1151 & 570 & 499 & 1411 & 1157 & $\underline{58.6}$ & & & & & & & & & & & & & \\
\hline Xik & 299 & 864 & 646 & 647 & 251 & 472 & 910 & 472 & 474 & 146 & 228 & 1402 & 22.6 & & & & & & & & & & & & \\
\hline Ara & 511 & 1061 & 868 & 855 & 385 & 673 & 698 & 678 & 670 & 360 & 426 & 1573 & $\overline{170}$ & $\underline{29.7}$ & & & & & & & & & & & \\
\hline Kat & 339 & 448 & 367 & 618 & 839 & 244 & 837 & 194 & 268 & 204 & 552 & 992 & 389 & 603 & 13.7 & & & & & & & & & & \\
\hline Tir & 1094 & 1026 & 1754 & 1486 & 1301 & 685 & 526 & 860 & 530 & 937 & 727 & 1023 & 945 & 553 & $\overline{872}$ & 49.8 & & & & & & & & & \\
\hline Wai & 208 & 765 & 646 & 578 & 550 & 346 & 948 & 375 & 324 & 050 & 059 & 1242 & 132 & 339 & 318 & $\overline{786}$ & 22.0 & & & & & & & & \\
\hline Wap & 400 & 931 & 923 & 782 & 698 & 496 & 729 & 555 & 449 & 240 & 170 & 1328 & 296 & 188 & 528 & 349 & $\frac{153}{153}$ & $\underline{30.0}$ & & & & & & & \\
\hline Map & 1125 & 1139 & 2450 & 1207 & 1004 & 1030 & 819 & 1094 & 807 & 1370 & 929 & 972 & 1064 & 1196 & 1392 & 1208 & 1111 & 1166 & 60.0 & & & & & & \\
\hline Wyu & 475 & 821 & 305 & 708 & 754 & 629 & 1014 & 490 & 731 & 352 & 859 & 1597 & 411 & 600 & 245 & 1321 & 544 & 779 & 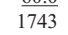 & $\underline{11.6}$ & & & & & \\
\hline Ksa & 651 & 1247 & 673 & 755 & 1136 & 759 & 1184 & 845 & 1036 & 520 & 861 & 1998 & 701 & 907 & 670 & 1538 & 633 & 837 & 1827 & $\overline{559}$ & 24.1 & & & & \\
\hline Iga & 790 & 1450 & 356 & 959 & 1450 & 1278 & 1637 & 1021 & 1483 & 685 & 1401 & 2530 & 979 & 1193 & 710 & 2048 & 979 & 1246 & 2719 & 360 & $\frac{1.14}{524}$ & $\underline{13.5}$ & & & \\
\hline $\mathrm{Car}$ & 1761 & 1079 & 2254 & 2099 & 2000 & 925 & 1134 & 1120 & 734 & 1621 & 1525 & 875 & 1659 & 1831 & 1076 & 1294 & 1530 & 1640 & 1568 & 1158 & 1782 & $\overline{2001}$ & $\underline{59.4}$ & & \\
\hline Mvk & 2207 & 1584 & 3232 & 2375 & 1984 & 1519 & 1531 & 1628 & 1242 & 2045 & 1486 & 1063 & 1937 & 1873 & 1984 & 1240 & 1733 & 1555 & 1294 & 2153 & 2328 & 3161 & 949 & 69.5 & \\
\hline Huc & 999 & 1174 & 1089 & 1272 & 1171 & 950 & 1398 & 916 & 965 & 869 & 1138 & 1540 & 866 & 1040 & 757 & 1503 & 949 & 1135 & 1469 & 761 & 1138 & 1407 & 1537 & 1607 & $\underline{36.0}$ \\
\hline
\end{tabular}

Yan, Yanomami; Asu, Asurini; Awa, Awá-Guajá; Gav, Gavião; Pak, Parakanã; Sui, Surui; Uru, Urubú-Kaapór; Wpi, Wayampi; Zoe, Zoé; Zor, Zoró; Kok, Kokraiomoro; Xav, Xavante; Xik, Xikrin; Ara, Arára; Kat, Katuena; Tir, Tiriyó; Wai, Wai-Wai; Wap, Wayana-Apalai; Map, Mapuche; Wyu, Wayuu; Kam, Kamsa; Ing, Inga; Car, Carrier-Sekani; Mvk, Mvskoke, Huc, Huichol. 
more differentiated and clearly separated from all other tribes, except the Xavante, from Brazil, and the Mapuche, from Argentina.

A restricted pool of ancestral haplotypes may explain the little diversity observed among most present-day Brazilian and Colombian Amerindian groups, while interethnic admixture could be the most important factor accounting for the high number of haplotypes and high levels of diversity observed in some South-American and most North-American tribes.

\section{References}

Antonarakis SE, Kazazian Jr, HH and Orkin SH (1985) DNA polymorphism and molecular pathology of the human -globin gene clusters. Hum Genet 69:1-14.

Bevilacqua LRM, Mattevi VS, Ewald GM, Salzano FM, Coimbra Jr CEA, Santos RV and Hutz MH (1995) Beta-globin gene cluster haplotype distribution in five Brazilian Indian tribes. Am J Phys Anthropol 98:395-401.

Callegari-Jacques SM and Salzano FM (1999) Brazilian Indian/non-Indian: interactions and their effects. Ciênc e Cult 51:166-174.

Castro-de-Guerra D, Hutz MH, Bortolini MC and Salzano FM (1997) Beta-globin gene cluster haplotypes in an admixed Venezuelan population. Am J Hum Biol 9:323-327.

Chen LZ, Easteal S, Board PG and Kirk RL (1990) Evolution of beta-globin haplotypes in human populations. Mol Biol Evol 7:423-437.

Excoffier L and Slatkin M (1995) Maximum-likelihood estimation of molecular haplotype frequencies in a diploid population. Mol Biol Evol 12:921-927.

Hill AVS, Bowden DK, O'Shaughnessy DF, Weatherall DJ and Clegg JB (1988) $\beta$-thalassemia in Melanesia: association with malaria and characterization of a common variant (IVS-1 nt $5 \mathrm{G} \rightarrow$ C). Blood 72:9-14.

Fucharoen G, Fucharoen S, Wilai Y, Chinoluck P, Khunsuk S, Sanchaisuriya K and Sae-Ung N (1997) Beta-globin gene haplotypes in some minor ethnic groups in Thailand. Sout As J Trop Med Publ Health 28:115-119.

Guerreiro JF, Figueiredo MS, Santos SEB and Zago MA (1992) $\beta$-globin gene cluster haplotypes in Yanomama Indians from the Amazon region of Brazil. Hum Genet 89:629-631.

Guerreiro JF, Figueiredo MS and Zago MA (1994) The $\beta$-globin gene cluster haplotypes of Amerindian populations from the Brazilian Amazon region. Hum Hered 44:142-149

Hewitt R, Krause A, Goldman A, Campbell G and Jenkins T (1996) $\beta$-globin haplotype analysis suggests that a major source of Malagasy ancestry is derived from Bantu-speaking Negroids. Am J Hum Genet 58:1303-1308.

Horai S, Kondo R, Nakagawa-Hattori Y, Hayashi S, Sonoda S and Tajima K (1993) Peopling of the Americas, founded by four major lineages of mitochondrial DNA. Mol Biol Evol 10:23-47.

Hundrieser J, Deka R, Gogoi BC, Papp T and Flatz G (1988a) Haplotypes and frameworks associated with the beta-globin gene in the Kachari population of Assam India. Hum Hered 38:240-245.

Hundrieser J, Sanguansermsri T, Papp T, Laig M and Flatz G. (1988b) $\beta$-globin gene linked DNA haplotypes and frame- works in three South-East Asian populations. Hum Genet 80:90-94.

Kaufman L, Carnese FR, Goicoechea A, Dejean C, Salzano FM and Hutz MH (1998) Beta-globin gene cluster haplotypes in the Mapuche Indians of Argentina. Genet Mol Biol 21:435437.

Kulozik AE, Wainscoat JS, Serjeant GR, Kar BC, Al-Awamy B, Essan GJF, Falusi AG, Hague SK, Hilali AM, Kate S, Ranasinghe WACP and Weatherall DJ (1986) Geographical survey of $\beta^{S}$-globin gene haplotypes: evidence for an independent Asian origin of the sickle-cell mutation. Am J Hum Genet 39:239-244.

Livshits G and Nei M. Relationships between intrapopulational and interpopulational genetic diversity in man (1990) Ann Hum Biol 17:501-513.

Long JC, Chakravarti A, Boehm CD, Antonarakis SE and Kazazian Jr HH (1990) Phylogeny of human beta-globin haplotypes and its implications for recent human evolution. Am J Phys Anthropol 81:113-130.

Maggio A, Acuto S, Lo Gioco P, Di Marzo R, Giambona A, Sammarco P and Caronia F (1986) $\beta^{A}$ and $\beta^{\text {thal }}$ DNA haplotypes in Sicily. Hum Genet 72:229-230.

Mattevi VS, Fiegenbaum M, Salzano FM, Weiss KM, Moore J, Monsalve MV, Devine DV and Hutz MH (2000) Betaglobin gene cluster haplotypes in two North-American indigenous populations. Am J Phys Anthropol 1123:311-317.

Nei M (1978) Estimation of average heterozygosity and genetic distance from a small number of individuals. Genetics 89:583-590.

Nei M and Roychoudhury AK (1993) Evolutionary relationships of human populations on a global scale. Mol Biol Evol 10:927-943

Nei M, Tajima F and Tateno Y (1983) Accuracy of estimated phylogenetic trees from molecular data. J Mol Evol 19:153170.

Nei M (1973) Analysis of gene diversity in subdivided populations. Proc Natl Acad Sci USA 70:3321-3323.

Neves WA, Prous A, Powell JF and Ozolins EG (1998) Lapa Vermelha IV Hominid I: morphological affinities of the earliest known American. Am J Phys. Anthropol 26(suppl): 169.

Oehme R, Kohne E and Horst J (1985) DNA-Polymorphic patterns linked to the $\beta$-globin genes in German families affected with hemo-globinopathies and thalassemias: a comparison to other ethnic groups. Hum Genet 71:219-222.

Old JM and Higgs DR (1983) Gene analysis. In: D.J. Weatherall (ed) The Thalassemias: Methods in Hematology. Churchill Livingstone, Edinburg, pp 74-102.

Ota T (1993) DISPAN: Genetic distance and phylogenetic analysis. University Park, Institute of Molecular Genetics, Pensylvania State University. (http://evolution.genetics. washington.edu/phylip/software.dist.html\#DISPAN).

Penaloza R, Garcia-Carranca A, Ceras T, Alvarez C, Berumen J, Zavala C and Salamanca F (1995) Frequency of haplotypes in the beta-globin gene cluster in a selected sample of the Mexican population. Am J Hum Biol 7:45-49.

Ramsay M and Jenkins T (1987) Globin gene-associated restriction-fragment-length polymorphisms in Southern African peoples. Am J Hum Genet 41:1132-1144. 
Saitou N and Nei M (1987) The neighbor-joining method: A new method for reconstructing phylogenetic trees. Mol Biol Evol 4:406-425.

Salzano FM and Callegari-Jacques SM (1988) South-American Indians. A case study in evolution. Clarendon Press, Oxford, pp 1-20.

Shimizu K (1987) Characteristics of $\beta$ A chromosome haplotypes in Japanese. Biochem Genet 25:197-203.

Shimizu K, Hashimoto T, Harihara S, Tajima K, Sonoda S and Zaninovic V (2000) $\beta$-globin gene haplotype characteristics of Colombian Amerindians in South America. Hum Hered 51:54-63.

Shimizu K, Park KS, Harihara S and Enoki Y (1992) Relationships between $\% \mathrm{Hb}$ F or $\% \mathrm{G}$ gamma and the haplotypes in the beta-globin gene cluster in the normal adult Japanese and Korean populations. Hum Hered 42:216-21

Shimizu K, Park KS and Omoto K (1989) The DNA polymorphisms of the $\beta$-globin gene cluster and the arrangements of the $\alpha$-and the $\gamma$-globin genes in Koreans. Hemo-globin 13:137-146.

Swofford DL and Selander RK (1981) BIOSYS-1: A FORTRAN program for the comprehensive analysis of electrophoretic data in population genetics and systematics. Journal of Heredity $72: 281-283$.

Sutton M, Bouhassira EE and Nagel RL (1989) Polymerase chain reaction amplification applied to the determination of betalike-globin gene cluster haplotypes. Am J Hematol 32:6669.

Trent RJ, Ferguson V, Hertzberg MS, Rutherford J and Mickleson KNP (1990) $\beta$-globin gene haplotypes in Polynesians are predominantly Southern Chinese in type. Hum Hered 40:285-289.
Varawalla NY, Fitches AC and Old JM (1992) Analysis of $\beta$-globin gene haplotypes in Asian Indians: origin and spread of $\beta$-thalassaemia on the Indian subcontinent. Hum Genet 90:443-449.

Villalobos-Arámbula A.R, Rivas F, Sandoval L, Perea FJ, CasasCastañeda JM, Cantu JM and Ibarra B (2000) $\beta^{A}$-globin gene haplotypes in Mexican Huichols: genetic relatedness to other populations. Am J Hum Biol 12:201-206.

Vincek V, Bontrop R, O'huigin C and Figueroa F (1994) Polymorphism of the $\beta$-globin region in apes: implications for the origin of human haplotypes. Mam Genome 5:376-379.

Wainscoat JS, Hill AVS, Boyce AL, Flint J, Hernandez M, Thein SL, Old JM, Lynch JR, Falusi AG, Weatherall DJ and Clegg JB (1986) Evolutionary relationships of human populations from an analysis of nuclear DNA polymorphisms. Nature 319:491-493.

Ward RH, Frazier BL, Dew-Jager K and Pääbo S (1991) Extensive mitochondrial diversity within a single Amerindian tribe. Proc Natl Acad Sci USA 88:8720-8724.

Yongvanit P, Sriboonlue P, Mularlee N, Karnthong T, Areejitranusorn P, Hundrieser J, Limberg R, Schulze B, Laig M, Flatz SD and Flatz G (1989) DNA haplotypes and frameworks linked to the $\beta$-globin locus in an AustroAsiatic population with a high prevalence of hemo-globin E. Hum Genet 83:171-174.

Zago MA, Silva WA, Tavella MH, Santos SEB, Guerreiro JF and Figueiredo MS (1996) Interpopulational and intrapopulational genetic diversity of Amerindians as revealed by six variable number of tandem repeats. Hum Hered 46:274-289. 